\title{
Analisis Lokasi Black Spot dan Black Link pada Jalan Poros Baubau-Kapontori
}

\author{
Ahmad Efendi ${ }^{1 *}$, Idwan ${ }^{1}$, Safrin Suhardin ${ }^{1}$, Wa Ode Salfia Ali Kasa ${ }^{1}$, Rizal Upu ${ }^{1}$ \\ ${ }^{1}$ Prodi Teknik Sipil, Fakultas Teknik, Universitas Muhammadiyah Buton, Indonesia \\ Korespondensi: fahlan.efendi@gmail.com
}

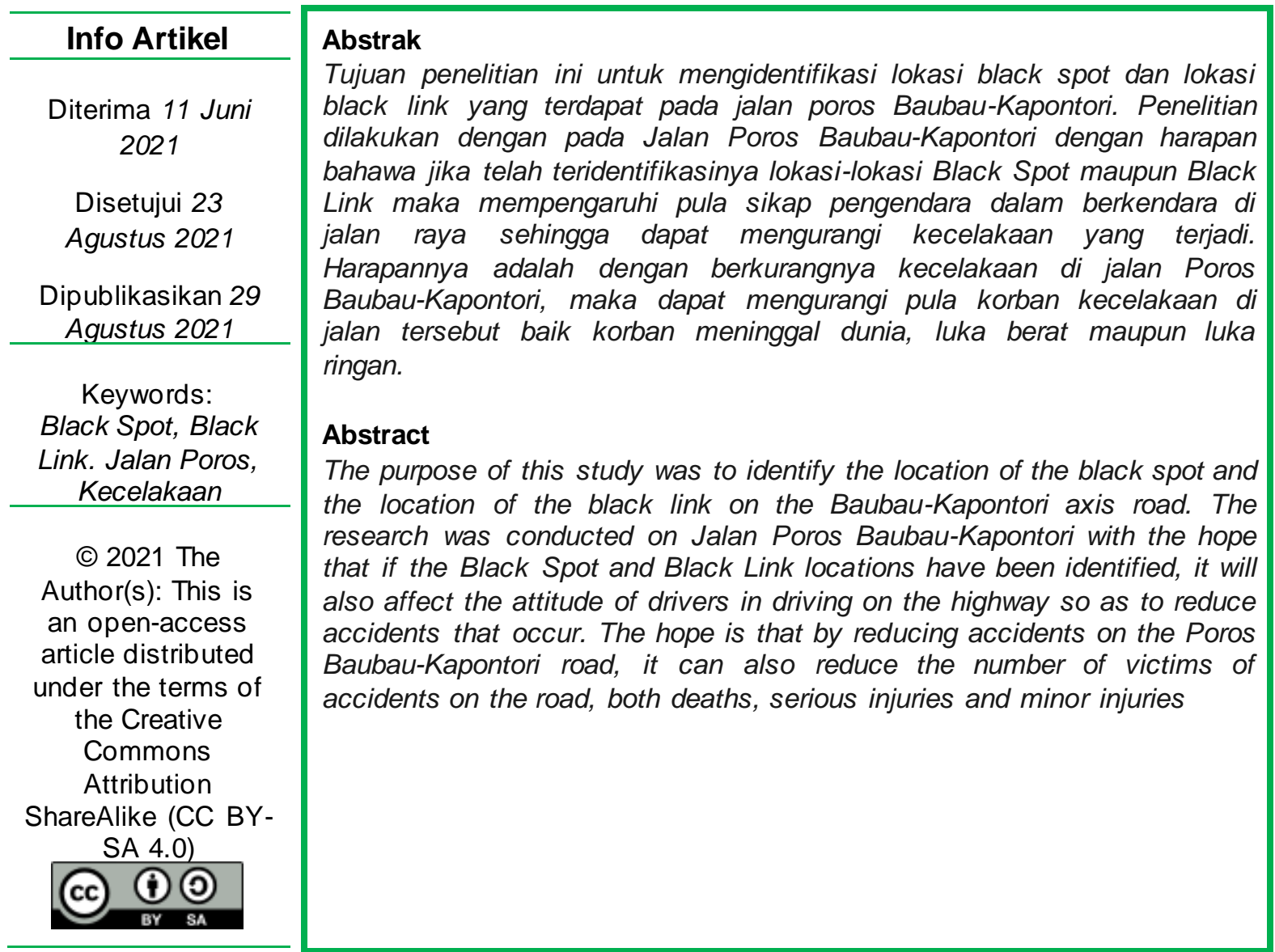

\section{Pendahuluan}

Kecelakaan lalu lintas merupakan salah satu masalah besar yang dihadapi oleh pemerintah Indonesia saat ini dimana mengalami peningkatan jumlah setiap tahunnya (Ermawati, Sugiyanto, \& Indriyati, 2019; Oktopianto \& Pangesty, 2021). Hal ini didasari dengan semakin bertambahnya penggunaan kendaraan bermotor baik roda dua maupun roda empat atau lebih (Agustin, Meidiana, \& Muljaningsih, 2020). Peningkatan jumlah kendaraan ini selaras dengan peningkatan jumlah kecelakaan yang terjadi di jalan raya. Berdasarkan data Kepolisian Negara 
Republik Indonesia, bahwa terjadi peningkatan jumlah kecelakaan di jalan pada tahun 2019 sebesar 3\% dari tahun sebelumnya. Dalam keterangan pers yang dilakukan Kepala Kepolisian Republik Indonesia menyebutkan bahwa selama tahun 2019 peristiwa kecelakaan lalu lintas berjumlah 105.500 kasus mengalami peningkatan jika dibandingkan tahun lalu sejumlah 103.672 kasus kecelakaan .

Tingginya kecelakaan Ialu lintas jalan raya, menimbulkan kerugian yang sangat tinggi pula baik berupa harta benda maupun korban nyawa (Setyarini \& Lukito, 2020). Kecelakaan lalu lintas di Kabupaten Buton pada bulan Agustus 2020 menurut data Satuan Lalu Lintas (Satlantas) Polres Buton mencapai 24 kasus angka kecelakaan yang mana 14 diantaranya langsung meninggal dunia.

Faktor-faktor penyebab kecelakaan lalu lintas ini sangat bervariasi dan bahkan suatu kecelakaan dapat terjadi karena disebabkan oleh beberapa faktor. Faktor-faktor penyebab kecelakaan dapat dikelompokkan menjadi 4 (empat) faktor yaitu faktor manusia, faktor kendaraan, faktor jalan, dan faktor lingkungan (Enggarsasi \& Sa'diyah, 2017; Kusuma, Sumarna, Mustika, \& Demar, 2019). Pada umumnya kecelakaan yang terjadi lebih banyak disebabkan oleh faktor manusia (Setiawan \& Asima, 2019). Hal ini senada dengan pernyataan Kapolres Buton yang menyebutkan bahwa pada tahun 2020 tingkat kecelakaan di Buton mengalami peningkatan dengan penyebab utama kecelakaan adalah faktor manusia yang disebabkan kurangnya kesadaran pengendara karena pengaruh minuman keras.

Kondisi ini perlu adanya suatu tindakan preventif untuk mengurangi tingkat kecelakaan lalu lintas, salah satunya adalah menentukan daerah rawan kecelakaan yang terdiri dari penentuan daerah black spot maupun daerah black link (Sugiyanto \& Fadli, 2017). Salah satu cara yang dapat dilakukan adalah dengan mengidentifikasi daerah rawan kecelakaan menjadi titik rawan kecelakaan (black spot) dan jalur rawan kecelakaan (black link). Dengan diketahuinya lokasi tersebut maka dapat dilakukan penanganan-penanganan di daerah tersebut gu na mencegah dan mengurangi tingkat kecelakaan yang terjadi serta dapat dilakukan analisa terhadap penyebab kecelakaan di titik dan jalur tersebut.

Penelitian dengan judul yang sama telah pernah dilakukan oleh penelitipeneliti lainnya dalam bidang transportasi namun masih sedikit yang memasukkan variable black link sebagai salah satu variable yang diteliti. Kebanyakan penelitian sejenis berkisar pada pencarian daerah black spot dan black site sehingga, namun penelitian sejenis di daerah Buton baik lokasi penelitian Kota Baubau, Kabu paten Buton, Kabupaten Buton Selatan masih sangat terbatas.

\section{Metode Penelitian}

Penelitian ini diawali dengan menentukan daerah atau lokasi penelitian yang mana daerah penelitian yang terpilih adalah jalan poros Baubau-Kapontori. Jalan poros Baubau-Kapontori merupakan jalan penghubung antara kota Baubau dengan Kabupaten Buton (Kecamatan Kapontori), dimana jalan poros ini memiliki intensitas transportasi yang tinggi. Hal ini dikarenakan jalan poros BaubauKapontori banyak dilalui oleh kendaraan roda dua, roda empat maupun lebih yang dari Baubau menuju Kapontori, Lawele, Kabupaten Wakatobi, Kabupaten Bombana dan bahkan Kota Kendari. 
Volume kendaraan yang padat pada jalan poros Baubau-Kapontori, ditambah lagi dengan sempitnya jalan dan kondisi jalan dengan banyak tikungan menyebabkan sering terjadi kecelakaan di jalan ini. Untuk mengantisipasi hal tersebut maka perlu diketahui titik-titik mana saja yang rentan terhadap kecelakaan sehingga pengemudi kendaraan baik roda dua, roda empat mapun lebih dapat berhati-hati ketika melintas pada jalan ini. Sehingga dengan demikian dapat mengurangi kecelakaan yang terjadi di jalan ini.

\subsection{Lokasi dan Waktu Penelitian}

Penelitian ini dilakukan di Jalan Poros Baubau-Kapontori tepatnya dari simpang Hotel Ratu Rajawali sampai dengan Kelurahan Wakangka dengan jarak sejauh $\pm 40 \mathrm{Km}$. Adapun lokasi penelitian diperlihatkan pada gambar 3.1 berikut ini.

\subsection{Teknik Pengumpulan Data}

Pengumpulan data dalam penelitian ini dilakukan dengan mengumpulkan data primer dan data sekunder. Data primer berupa data yang dikumpulkan langsung melalui pengamatan dan pengukuran di lapangan atau sepanjang jalan Poros Baubau-Kapontori. Sedangkan data sekunder diperoleh dari data register kecelakaan Polres Buton untuk mengetahui jumlah kecelakaan yang terjadi, korban kecelakaan, kerugian biaya yang diderita serta lokasi-lokasi terjadinya kecelakaan.

\subsection{Teknik Pengolahan Data}

Data primer dan data sekunder yang telah dikumpulkan selanjutnya dilakukan pengolahan data untuk menentukan daerah atau titik-titik yang rawan kecelakaan sepanjang jalan Poros Baubau-Kapontori. Pengukuran dilakukan untuk memperoleh data panjang jalan dari titik awal di simpang Hotel Ratu Rajawali sampai dengan titik akhir di batas Kelurahan Wakangka.

Data kecelakaan lalu lintas baik jumlah kecelakaan, korban kecelakaan, kerugian yang diderita, dan lokasi-lokasi kecelakaan digunakan untuk menentukan lokasi Black Spot dan Black Link sepanjang jalan Poros Baubau-Kapontori. Datadata ini selanjutnya diolah dengan menggunakan metode Ekivalensi Angka Kecelakaan untuk menentukan lokasi Balck Spot dan Black Link. Kemudian kedua lokasi ini ditentukan juga dengan menggunakan metode Batas Kelas Atas (BKA). Setelah diperoleh daerah lokasi Black Spot dan Black Link dari kedua metode tersebut, maka ditentukan kembali lokasi Black Spot dan Black Link dengan memperhatikan dua metode yang digunakan. Lokasi Black Spot dan Black Link yang baru atau yang terpilih adalah lokasi-lokasi Black Spot dan Black Link yang sama pada kedua metode tersebut, dan jika hanya salah satu yang menunjukkan Black Spot dan Black Link maka lokasi tersebut tidak dapat dikategorikan sebagai Black Spot maupun Black Link.

Penelitian ini menggunakan data kecelakaan selama 3 (tiga) tahun sejak tahun 2017 sampai dengan tahun 2019. Data ini diperlihatkan pada tabel 4.1 berikutini. 
Tabel 4.1 Data Kecelekaan Lalu Lintas 2017-2019

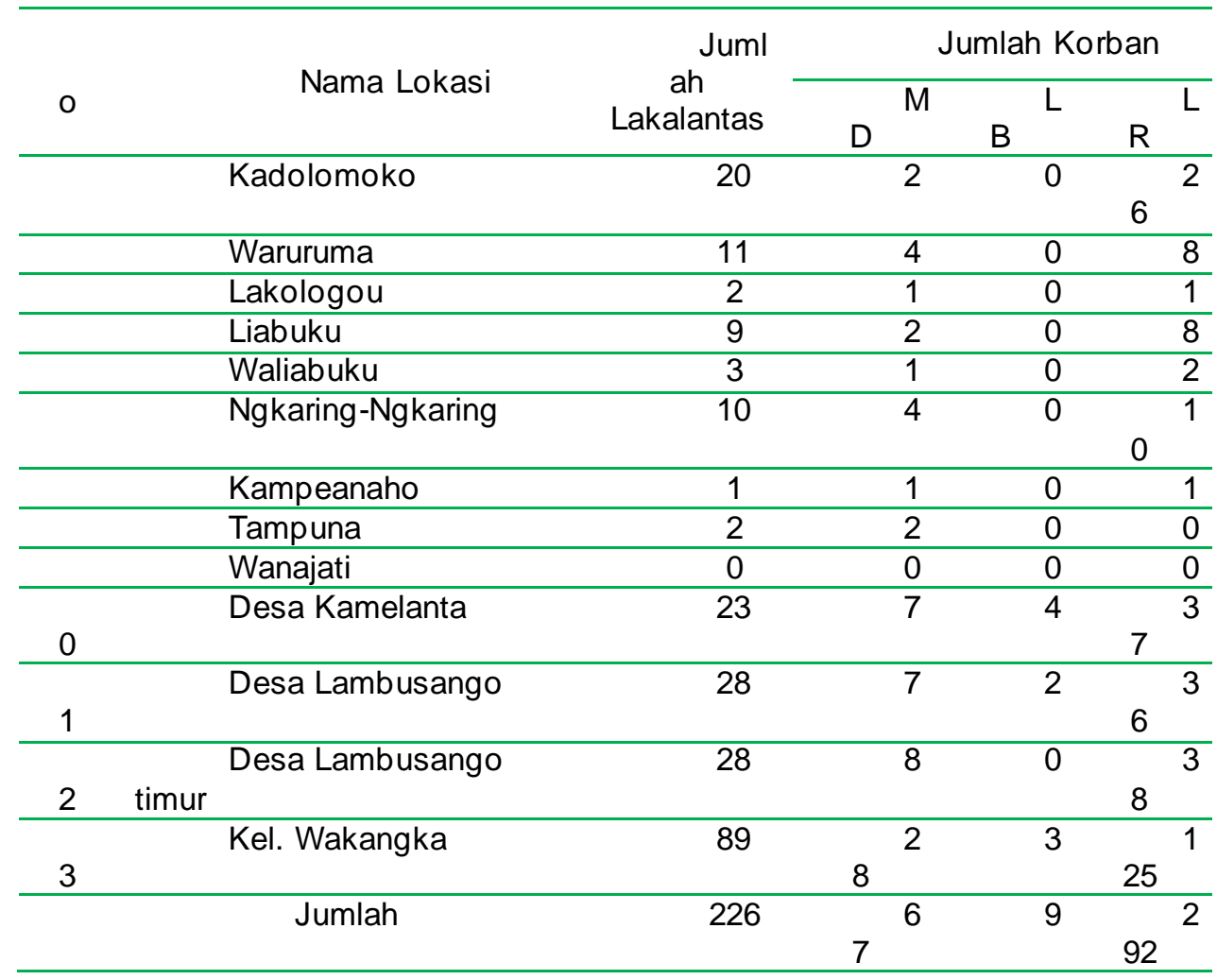

Sumber: Satlantas Kota Baubau \& Kab. Buton, 2021

Ket: MD = Meninggal Dunia

$$
\begin{aligned}
& L B=\text { Luka Berat } \\
& L R=\text { Luka Ringan }
\end{aligned}
$$

\subsubsection{Analisa Black Spot}

Penentuan lokasi Black Spot dalam penelitian ini menggunakan beberapa metode yaitu metode Z-Score, metode EAN, metode BKA dan metode UCL.

1) Metode Z-Score

Untuk menentukan daerah rawan kecelakaan (black site ) Digunakan rumus Z-score.Dengan menggunakan rumus tersebut diketahui tingkat pertumbu han ratarata kejadian kecelakaan dan daerah rawan kejadian kecelakaan yang ada di ruas jalan Baubau - Kapontori.

Perhitungan Z-score untuk pertumbuhan tingkat kecelakaan pada tahun 2017 sampai dengan tahun 2019.

a. Mencari Nilai Rata-rata Data

$$
x=\frac{\sum x}{n}=\frac{226}{13}=17,4
$$

Nilai rata-rata $X$ adalah jumlah angkah kecelakaan tahun 2017 sampai dengan tahun 2019 dibagi dengan jumlah data, dimana angka jumlah kecel akaan 
226 kejadian dan jumlah data 13 ruas jalan.Perhitungan lebis jelasnya ada pada lampiran.

b. Mencari Nilai Standar Deviasi

$$
S=\sqrt{\frac{\sum(x-x)^{2}}{n}}=\sqrt{\frac{6809,1}{13}}=22,9
$$

Nilai standar deviasi (S) adalah akar dari jumlah kuadrat dari rata-rata angka kecelakaan tahun 2017 sampai dengan taahun 2019 di kurangi rata-rata angka kecelakaan dibagi dengan jumlah data, dimana jumlah kuadrat rata-rata angka kecelakaan tahun 2017 sampai dengan tahun 2019 dikurangi rata2 angka kecelakaan sebesar 6809,1, dibagi denagn jumlah data sebesar 13. Perhitungan lebih detailnya terlihat pada tabel 4.2.

c. Mencari Nilai $Z i$

$$
Z i=\frac{x i-x}{s}=\frac{20-17,4}{22,9}=0,1
$$

Nilai Z- Score adalah Rata-rata angka kecelakaan pertahun dikurangi ratarata angka kecelakaan dibagi standar deviasi, dimana dalam contoh perhitungan ini di ambil ruas jalan kadolomoko dengan jumlah angka rata-rata kecelakaan 20 kecelakaan, nilai rata-rata kecelakaan sebesar 17,4, dan nilai standar deviasi sebesar 22,9. Perhitungan lebih detailnya lita pada lampirannya.

Tabel 4.2 Hasil analisa Z- ScOre untuk identifikasi titik rawan

\begin{tabular}{|c|c|c|c|c|c|}
\hline No & Lokasi & $\begin{array}{l}\text { Jumlah } \\
\text { Kecelakaan }\end{array}$ & $\mathbf{Z}$ & Kelas & Keterangan \\
\hline 1. & Kadolomoko & 20 & 0,1 & IV & $\begin{array}{c}\text { Rawan Kecelakaan } \\
\text { Rendah }\end{array}$ \\
\hline 2. & Waruruma & 11 & - & & $\begin{array}{l}\text { Tidak Rawan } \\
\text { Kecelakaan }\end{array}$ \\
\hline 3. & Lakologou & 2 & 0,7 & & $\begin{array}{l}\text { Tidak Rawan } \\
\text { Kecelakaan }\end{array}$ \\
\hline 4. & Liabuku & 9 & 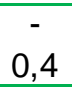 & & $\begin{array}{l}\text { Tidak Rawan } \\
\text { Kecelakaan }\end{array}$ \\
\hline 5. & Waliabuku & 3 & - & & $\begin{array}{l}\text { Tidak Rawan } \\
\text { Kecelakaan }\end{array}$ \\
\hline 6. & Ngkaring - Ngkaring & 10 & 0,3 & & $\begin{array}{l}\text { Tidak Rawan } \\
\text { Kecelakaan }\end{array}$ \\
\hline 7. & Kampeonaho & 1 & 0,7 & & $\begin{array}{l}\text { Tidak Rawan } \\
\text { Kecelakaan }\end{array}$ \\
\hline 8. & Tampuna & 2 & 0,7 & & $\begin{array}{l}\text { Tidak Rawan } \\
\text { Kecelakaan }\end{array}$ \\
\hline 9. & Wanajati & 0 & 0,8 & & $\begin{array}{l}\text { Tidak Rawan } \\
\text { Kecelakaan }\end{array}$ \\
\hline 10. & Desa kamelanta & 23 & 0,2 & III & $\begin{array}{c}\text { Rawan Kecelakaan } \\
\text { Rendah }\end{array}$ \\
\hline 11 & Desa lambusango & 28 & 0,5 & & \\
\hline 12 & $\begin{array}{c}\text { Desa Lambusango } \\
\text { Timur }\end{array}$ & 28 & 0,5 & II & $\begin{array}{c}\text { Rawan Kecelakaan } \\
\text { Rendah }\end{array}$ \\
\hline 13 & Kelurahan Wakangka & 29 & 3,1 & I & $\begin{array}{c}\text { Rawan Kecelakaan } \\
\text { Sangat Tinggi }\end{array}$ \\
\hline
\end{tabular}
kecelakaan (Black Site) Lalu lintas (Sumber: Hasil Analisa, 2021) 
Berdasarkan Tabel 4.2 dapat di ketahui kriteria rawan kecelakaan jalan poros Baubau-Kapuntori meliputi sangat tinggi, rendah, dan tidak rawan kecelakaan . Adapun ruas jalan tersebut anatara lain pada kelu rahan wakangka dengan kriteria rawan kecelakaan sangat tinggi dan memiliki nilai Z-Score sebesar 3,1, ruas jalan dengan kriteria rawan kecelekaan rendah meliputi ruas jalan desa lambusango ,desa lambusango timur, desa Kamelanta dan Kadolomoko.Adapun ruas jalan yang teridentifikasi tidak rawan kecelakaan meliputi ruas jalan waruruma, lakologou,liabuku, waliabuku, ngkaring-ngkaring, kampeanaho, tampuna dan wanajati.

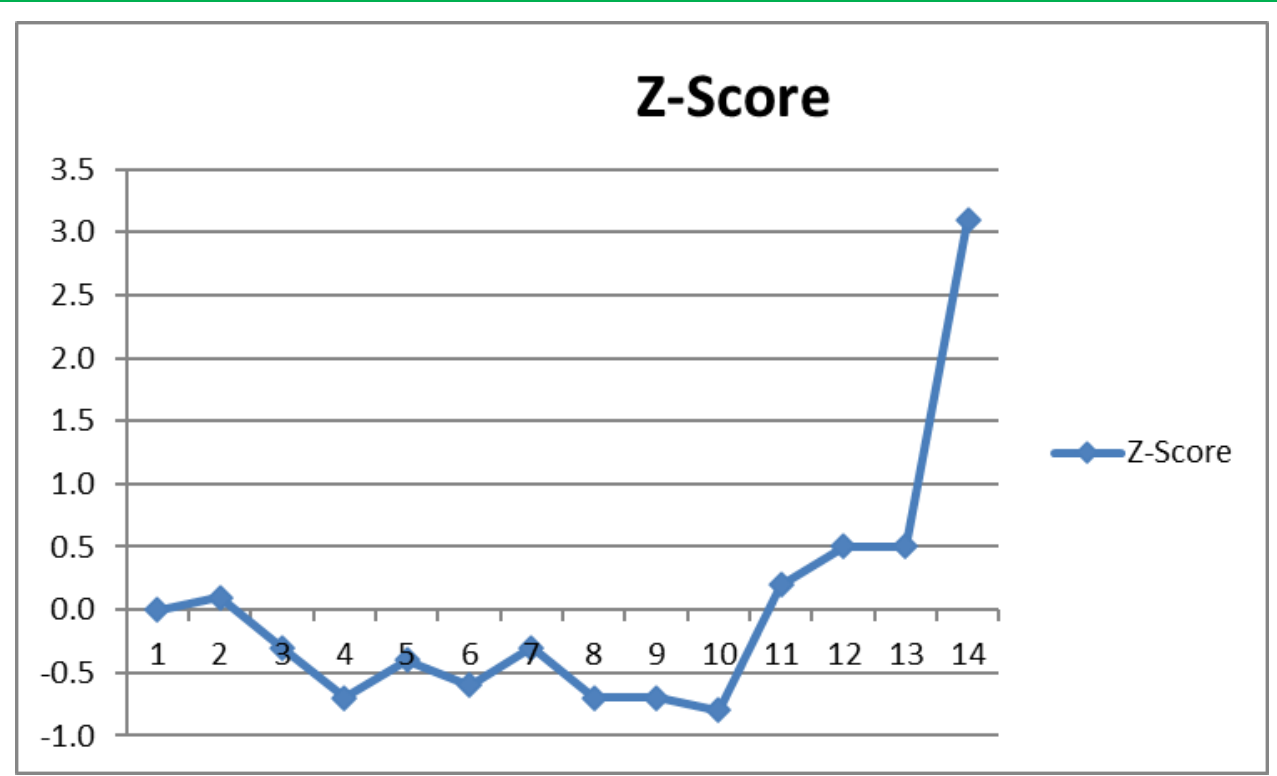

Gambar 4.1.Nilai Z-Score Jalur Baubau-Kapuntori (Kadolomoko-Kel. Wakangka)

\section{2) Metode EAN}

Berdasarkan jumlah korban kecelakaan lalu lintas pada data maka dapat dilakukan perhitungan angka kecelakaan pada jalan Baubau - Kapuntori (dari Kadolomoko- Kel. Wakangka) menggunakan metode EAN. Berdasarkan data kecelakaan yang terjadi pada ruas jalan kadolomoko Jalur A sebagaimana diperlihatkan pada tabel 4.1 di atas, dimana jumlah kecelakaan selama 3 (tiga) tahun sebanyak 20 kecelakaan yang mengakibatkan 2 orang meninggal dunia, luka berat tidak ada dan 26 orang mengalami luka ringan, sehingga diperoleh nilai EAN untuk Jalur $A$, sebagai berikut :

Jalur $A$ : $E A N=(12 \times 2)+(6 \times 0)+(3 \times 26)+(1 \times 1)=133$

Jadi nilai EAN angka kecelakaan pada ruas Jalan Jalur A (Kadolomoko) adalah sebesar 133

Sedangkan untuk jalur B, C, D, E, F, G, H, I, J, K, L, dan M diperlihatkan pada tabel 4.3 di bawah ini.

Tabel 4.3. Nilai EAN (Sumber : Hasil Analisis Data, 2021)

\begin{tabular}{|c|c|c|c|c|c|c|}
\hline \multirow{2}{*}{ No. } & \multirow{2}{*}{ Jalur } & \multicolumn{3}{|c|}{$\begin{array}{l}\text { Jumlah Korban } \\
\text { Kecelakaan }\end{array}$} & \multirow{2}{*}{$\begin{array}{c}\text { Angka } \\
\text { Kecelakaan } \\
\text { EAN }\end{array}$} & \multirow[b]{2}{*}{ Keterangan } \\
\hline & & $\begin{array}{l}\text { Meninggal } \\
\text { Dunia }\end{array}$ & $\begin{array}{l}\text { Luka } \\
\text { Berat }\end{array}$ & $\begin{array}{l}\text { Luka } \\
\text { Ringan }\end{array}$ & & \\
\hline
\end{tabular}




\begin{tabular}{ccccccc}
\hline 1. & $\mathrm{~A}$ & 2 & 0 & 26 & 133 & Kadolomoko \\
\hline 2. & $\mathrm{~B}$ & 4 & 0 & 8 & 73 & Waruruma \\
\hline 3. & $\mathrm{C}$ & 1 & 0 & 1 & 16 & Lakologou \\
\hline 4. & $\mathrm{D}$ & 2 & 0 & 8 & 74 & Liabuku \\
\hline 5. & $\mathrm{E}$ & 1 & 0 & 2 & 19 & Waliabuku \\
\hline 6. & $\mathrm{~F}$ & 4 & 0 & 10 & 79 & Ngkaring-ngkaring \\
\hline 7. & $\mathrm{G}$ & 1 & 0 & 1 & 16 & Kampeanaho \\
\hline 8. & $\mathrm{H}$ & 2 & 0 & 0 & 25 & Tampuna \\
\hline 9. & $\mathrm{I}$ & 0 & 0 & 0 & 0 & Wanajati \\
\hline 10. & $\mathrm{~J}$ & 7 & 4 & 37 & 220 & Desa Kamelanta \\
\hline 11. & $\mathrm{~K}$ & 7 & 2 & 36 & 205 & $\begin{array}{c}\text { Deasa } \\
\text { Lambusango }\end{array}$ \\
\hline 12. & $\mathrm{~L}$ & 8 & 0 & 38 & 211 & Desa Lambusango \\
Timur
\end{tabular}

Berdasarkan hasil analisa data korban kecelakaan yang diperoleh dari kepolisian selama 3 Tahun terakhir adalah:

\section{a. Jalur A (Kadolomoko)}

Berdasarkan data kecelakaan selama 3 tahun terakhir yang diperoleh dari kepolisian pada Jalur ini terdapat 2 orang meninggal dunia, luka berat tidak ada, dan luka ringan sebanyak 26 orang. Sehingga berdasarkan data-data tersebut di peroleh nilai EAN pada Jalur A sebesar 133.

\section{b. Jalur B (Waruruma)}

Berdasarkan data kecelakaan selama 3 tahun terahir yang di peroleh dari kepolisian pada Jalur ini terdapat 4 orang meninggal dunia, luka berat tidak ada, dan luka ringan sebanyak 8 orang. Sehingga berdasarkan data-data tersebut di peroleh nilai EAN pada Jalur B sebesar 73.

c. Jalur C (Lakologou)

Berdasarkan data kecelakaan selama 3 tahun terahir yang di peroleh dari kepolisian pada Jalur ini terdapat 1 orang meninggal dunia, luka berat tidak ada, dan luka ringan sebanyak 1 orang. Sehingga berdasarkan data-data tersebut di peroleh nilai EAN pada Jalur C sebesar 16.

\section{d. Jalur D (Liabuku)}

Berdasarkan data kecelakaan selama 3 tahun terahir yang di peroleh dari kepolisian pada Jalur ini terdapat 2 orang meninggal dunia, luka berat tidak ada, dan luka ringan sebanyak 8 orang. Sehingga berdasarkan data- data tersebut di peroleh nilai EAN pada Jalur D sebesar 74 .

e. Jalur E (Waliabuku)

Berdasarkan data kecelakaan selama 3 Tahun terahir yang di peroleh dari kepolisian pada Jalur ini terdapat 1 orang meninggal dunia, luka berat tidak ada, dan luka ringan sebanyak 2 orang. Sehingga berdasarkan data-data tersebut di peroleh nilai EAN pada Jalur A sebesar 19. 


\section{f. Jalur F (Ngkaring-ngkaring)}

Berdasarkan data kecelakaan selama 3 Tahun terahir yang di peroleh dari kepolisian pada Jalur ini terdapat 4 orang meninggal dunia, luka berat tidak ada, dan luka ringan sebanyak 10 orang. Sehingga berdasarkan data-data tersebut di peroleh nilai EAN pada Jalur $\mathrm{F}$ sebesar 79.

\section{g. Jalur G (Kampeanaho)}

Berdasarkan data kecelakaan selama 3 Tahun terahir yang di peroleh dari kepolisian pada Jalur ini terdapat 1 orang meninggal dunia, luka berat tidak ada, dan luka ringan sebanyak 1 orang. Sehingga berdasarkan data- data ersebut di peroleh nilai EAN pada Jalur $G$ sebesar 16.

\section{h. Jalur H (Tampuna)}

Berdasarkan data kecelakaan selama 3 Tahun terahir yang di peroleh dari kepolisian pada Jalur ini terdapat 2 orang meninggal dunia, luka berat tidak ada, dan luka ringan tidak ada. Sehingga berdasarkan data-data tersebut di peroleh nilai EAN pada Jalur $\mathrm{H}$ sebesar 25.

\section{i. Jalur I (Wanajati)}

Berdasarkan data kecelakaan selama 3 Tahun terahir yang diperoleh dari kepolisian pada Jalur ini terdapat orang meninggal dunia tidak ada, luka berat tidak ada, dan luka ringan tidak ada. Sehingga berdasarkan data-data tersebut di peroleh nilai EAN pada Jalur i sebesar 0 .

j. Jalur J (Desa Kamelanta)

Berdasarkan data kecelakaan selama 3 Tahun terahir yang di peroleh dari kepolisian pada Jalur ini terdapat 7 orang meninggal dunia, luka berat 4 orang, dan luka ringan sebanyak 37 orang. Sehingga berdasarkan data tersebut di peroleh nilai EAN Jalur J sebesar 220.

\section{k. JalurK (Desa Lambusango)}

Berdasarkan data kecelakaan selama 3 Tahun terahir yang diperoleh dari kepolisian pada Jalur ini terdapat 7 orang meninggal dunia, luka berat 2 orang, dan luka ringan 36 orang. Sehingga berdasarkan data-data tersebut di peroleh nilai EAN pada Jalur K sebesar 205

\section{Jalur L (Desa Lambusango Timur)}

Berdasarkan data kecelakaan selama 3 Tahun terahir yang diperoleh dari kepolisian pada Jalur ini terdapat 8 orang meninggal dunia, luka berat tidak ada, dan luka ringan 38 orang. Sehingga berdasarkan data-data tersebut di peroleh nilai EAN pada Jalur $L$ sebesar 211.

$$
\text { m. Jalur M (Kel. Wakangka) }
$$

Berdasarkan data kecelakaan selama 3 Tahun terahir yang diperoleh dari kepolisian pada Jalur ini terdapat 28 orang meninggal dunia, luka berat 3 orang, dan luka ringan 1138,6 orang. Sehingga berdasarkan data-data tersebut di peroleh nilai EAN pada Jalur M sebesar 730. 


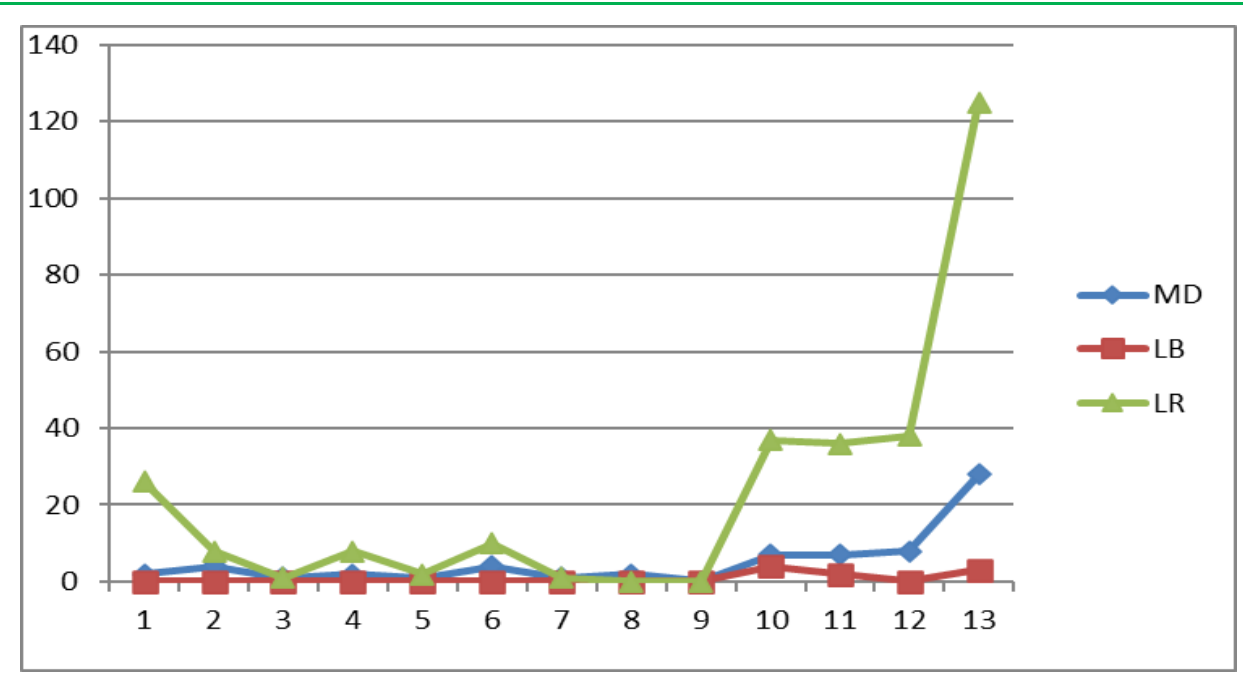

Gambar 4.2. Nilai EAN Jalur Baubau-Kapuntori (Kadolomoko-Kel. Wakangka)

Berdasarkan hasil perhitungan angka kecelakaan EAN seperti yang ditampilkan pada gambar 4.2, maka dapat dideskripsikan Nilai EAN di masing masing segmen sebagai berikut Jalur $A=133$, Jalur $B=73$, Jalur $C=16$, Jalur $D=$ 74, Jalur $E=19$, Jaluran $F=79$, Jalur $G=16$, Jalur $H=25$, Jalur $I=1$, Jalur $\mathrm{J}=$ 220 , Jalur $K=205$, Jalur $L=211$, Jalur $M=730$. Serta dapat diketahui angka $E A N$ tertinggi yaitu pada Jaluran $\mathrm{M}=730$, sedangkan angka $\mathrm{EAN}$ terendah yaitu pada Jalur I = 0 .

Berdasarkan hasil perhitungan angka kecelakaan seperti yang ditampilkan pada Tabel 4.3, maka dapat diurutkan (perangkingan) pada ruas titik rawan kecelakaan (black spot) berdasarkan nilai EAN angka kecelakaan tertinggi seperti pada Tabel 4.4 .

Tabel 4.4. Penetapan Rangking berdasarkan Nilai EAN (Sumber: Hasil Analisis Data,2021)

\begin{tabular}{cccc}
\hline No. & Jalur & $\begin{array}{c}\text { Angka Kecelakaan } \\
\text { EAN }\end{array}$ & Rangking \\
\hline 1. & $\mathrm{M}$ & 730 & 1 \\
\hline 2. & $\mathrm{~J}$ & 220 & 2 \\
\hline 3. & $\mathrm{~K}$ & 205 & 3 \\
\hline 4. & $\mathrm{~L}$ & 211 & 4 \\
\hline 5. & $\mathrm{~A}$ & 133 & 5 \\
\hline 6. & $\mathrm{~F}$ & 79 & 6 \\
\hline 7. & $\mathrm{D}$ & 74 & 7 \\
\hline 8. & $\mathrm{~B}$ & 73 & 8 \\
\hline 9. & $\mathrm{H}$ & 25 & 9 \\
\hline 10. & $\mathrm{E}$ & 19 & 11 \\
\hline 11. & $\mathrm{C}$ & 16 & 12 \\
\hline 12. & $\mathrm{G}$ & 16 & \\
\hline 13. & $\mathrm{I}$ & 0 & \\
\hline & Jumlah & 1802 & \\
\hline
\end{tabular}


Berdasarkan table 4.4 diatas nilai EAN angka kecelakaan tertinggi seperti pada gambar di atas dapat dideskripsikan yang berada di peringkat pertama yaitu Jalur $\mathrm{M}(\mathrm{EAN}=730)$, yang berada di peringkat kedua yaitu Jalur $\mathrm{J}(E A N=220)$, yang berada di peringkat ketiga yaitu Jalur $\mathrm{K}(\mathrm{EAN}=205)$, yang berada di peringkat keempat yaitu Jalur $L(E A N=221)$, yang berada di peringkat kelima yaitu Jalur A (EAN = 133), Jalur C, yang berada di peringkat keenam yaitu Jalur $F$ (EAN $=79)$, yang berada di peringkat ketujuh yaitu Jalur $\mathrm{D}(\mathrm{EAN}=74)$, yang berada diperingkat kedelapan yaitu Jalur B (EAN = 73),yang berada diperingkat kesembilan yaitu Jalur $\mathrm{H}(\mathrm{EAN}=25)$, yang berada diperingkat kesepuluh yaitu Jalur $E(E A N=19)$, yang berada di peringkat kesebelas yaitu Jalur $C$ dan $E$ (EAN $=16)$, dan peringkat keduabelas yaitu Jalur I $($ EAN $=0)$.

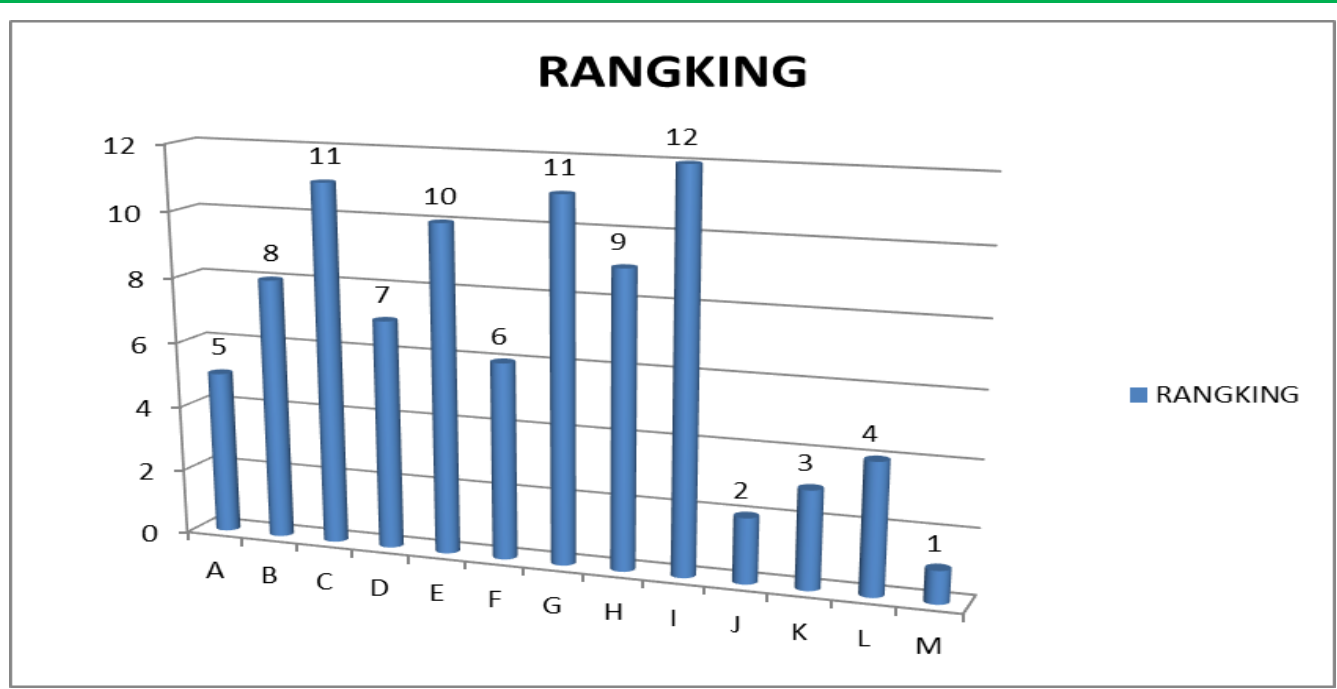

Gambar 4.3. Rangking EAN Jalur Baubau-Kapuntori (Dari KadolomokoKel.Wakangka

\subsubsection{Batas Kontrol Atas (BKA)}

Dengan jumlah total angka kecelakaan EAN = 1802 pada 13 segmen pengamatan, maka nilai rata-rata $(\mathrm{C})$ dapat dihitung sebagai berikut :

$$
C=1802 / 13=138,6
$$

Dengan nilai rata-rata $(C)=138,6$ maka nilai BKA dapat dihitung sebagai berikut :

$$
\begin{aligned}
B \boldsymbol{A} \boldsymbol{A}=138,6+3 \sqrt{138,6}=138,6+3(11,8) \\
=138,6+35,4 \\
=174
\end{aligned}
$$

Jadi, nilai batas control dengan metode BKA pada Jalur Baubau-Kapontori (Jalur A - Jalur M) adalah sebesar 174 angka kecelakaan.

Nilai BKA untuk semua Jalur Baubau-Kapuntori (dari Kadolomoko-Kel. Wakangka) sama atau seragam, yaitu 174 angka kecelakaan, karena pada persamaan tersebut hanya menggunakan nilai rata-rata dari angka kecelakaan EAN. 


\subsubsection{Upper Control Limit (UCL)}

Dengan jumlah total angka kecelakaan EAN =1802 pada 13 Jaluran pengamatan, maka nilai rata-rata $(\lambda)$ dapat dihitung sebagai berikut:

$\lambda=1802 / 13=138,6$

Faktor probabilitas $(\psi)=2,576$

Untuk segmen I (Jalur A) dengan nilai $m=133$,

Nilai rata-rata $(\lambda)=138,6$

factor probabilitas $\psi=2.576$,

Berdasarkan hal tersebut, maka nilai UCL dapat dihitung, sebagai berikut :

a. Jalur A (Kadolomoko)

Adapun nilai UCL untuk Jalur A diperoleh sebagai berikut:

$$
\begin{aligned}
& U C L=138,6+[2,576 \sqrt{(138,6 / 133)}]+[0.829 / 133]+[1 / 2 \times 133] \\
& =207,7
\end{aligned}
$$

b. Jalur B (Waruruma)

Adapun nilai UCL untuk Jalur A diperoleh sebagai berikut:

$$
U C L=138,6+[2,576 \sqrt{(138,6 / 73)}]+[0.829 / 73]+[1 / 2 \times 73]
$$

\section{$=178,7$}

c. Jalur C (Lakologou)

Adapun nilai UCL untuk Jalur C diperoleh sebagai berikut:

$$
U C L=138,6+[2,576 \sqrt{(138,6 / 16)}]+[0.829 / 16]+[1 / 2 \times 16]
$$

$$
=154,2
$$

d. Jalur D (Liabuku)

Adapun nilai UCL untuk Jalur D diperoleh sebagai berikut:

$$
U C L=138,6+[2,576 \sqrt{(138,6 / 74)}]+[0.829 / 74]+[1 / 2 \times 74]
$$

$$
=179,1
$$

e. Jalur $E$ (Waliabuku)

Adapun nilai UCL untuk Jalur E diperoleh sebagai berikut: 


$$
U C L=138,6+[2,576 \sqrt{(138,6 / 19)}]+[0.829 / 19]+[1 / 2 \times 19]
$$

$=155,1$

f. Jalur F (Ngkaring-ngkaring)

Adapun nilai UCL untuk Jalur F diperoleh sebagai berikut:

$$
\begin{aligned}
& U C L=138,6+[2,576 \sqrt{(138,6 / 79)}]+[0.829 / 79]+[1 / 2 \times 79] \\
& =181,5
\end{aligned}
$$

g. Jalur G (Kampeanaho)

Adapun nilai UCL untuk Jalur G diperoleh sebagai berikut:

$$
\begin{gathered}
U C L=138,6+[2,576 \sqrt{(138,6 / 16)}]+[0.829 / 16]+[1 / 2 \times 16] \\
=154,2
\end{gathered}
$$

h. Jaluran $\mathrm{H}$ (Tampuna)

Adapun nilai UCL untuk Jalur H diperoleh sebagai berikut:

$$
\begin{aligned}
& U C L=138,6+[2,576 \sqrt{(138,6 / 25)}]+[0.829 / 25]+[1 / 2 \times 25] \\
& =157,2
\end{aligned}
$$

i. Jaluran I (Wanajati)

Adapun nilai UCL untuk Jalur I diperoleh sebagai berikut:

$$
\begin{aligned}
& U C L=138,6+[2,576 \sqrt{(138,6 / 0)}+[0.829 / 0]+[1 / 2 \times 0] \\
& =138,6
\end{aligned}
$$

i. Jaluran J (Desa Kamelanta)

Adapun nilai UCL untuk Jalur J diperoleh sebagai berikut: 


$$
\begin{gathered}
C L=138,6+[2,576 \sqrt{(138,6 / 220)}]+[0.829 / 220 U] \\
+[1 / 2 \times 220] \\
=250,6
\end{gathered}
$$

j. Jalur K (Desa Lambusango)

Adapun nilai UCL untuk Jalur K diperoleh sebagai berikut:

$$
\begin{aligned}
C L=138,6+ & {[2,576 \sqrt{(138,6 / 205)}]+[0.829 / 205 U] } \\
& +[1 / 2 \times 205]
\end{aligned}
$$

$$
=243,2
$$

k. Jalur $L$ (Desa lambusango timur)

Adapun nilai UCL untuk Jalur $L$ diperoleh sebagai berikut:

$$
\begin{aligned}
C L=138,6+ & {[2,576 \sqrt{(138,6 / 211)}]+[0.829 / 211 U] } \\
& +[1 / 2 \times 211]
\end{aligned}
$$

\section{$=246,2$}

I. Jalur M (Kel. Wakangka)

Adapun nilai UCL untuk Jalur M diperoleh sebagai berikut:

$$
\begin{aligned}
C L=138,6+ & {[2,576 \sqrt{(138,6 / 730)}]+[0.829 / 730 U] } \\
& +[1 / 2 \times 730] \\
=504,7 &
\end{aligned}
$$

Nilai batas kontrol dengan metode BKA, UCL dan penentuan black spot selengkapnya dapat dilihat pada Tabel 4.5

Tabel 4.5 Data Metode EAN, BKA, UCL (Sumber: Hasil Analisis Data, 2021)

\begin{tabular}{cccccc}
\hline Jalur & $\begin{array}{c}\text { Metode } \\
\text { EAN }\end{array}$ & $\begin{array}{c}\text { Metode } \\
\text { BKA }\end{array}$ & Keterangan & $\begin{array}{c}\text { Metode } \\
\text { UCL }\end{array}$ & Keterangan \\
\hline A & 133 & 174 & - & 207,7 & - \\
\hline B & 73 & 174 & - & 178,7 & - \\
\hline C & 16 & 174 & - & 154,2 & - \\
\hline
\end{tabular}




\begin{tabular}{cccccc}
\hline D & 74 & 174 & - & 179,1 & - \\
\hline E & 19 & 174 & - & 155,1 & - \\
\hline F & 79 & 174 & - & 181,5 & - \\
\hline G & 16 & 174 & - & 154,2 & - \\
\hline H & 25 & 174 & - & 157,2 & - \\
\hline I & 0 & 174 & - & 138,6 & - \\
\hline J & 220 & 174 & Black Site & 250,6 & - \\
\hline K & 205 & 174 & Black Site & 243,2 & - \\
\hline L & 211 & 174 & Black Site & 246,2 & - \\
\hline M & 730 & 174 & Black Site & 504,7 & Black Site \\
\hline
\end{tabular}

Berdasarkan identifikasi black site yang dihitung menggunakan metode BKA seperti terlihat pada tabel 4.4 seluruh Jaluran dan Jalur memiliki nilai yang sama sebesar 174. Jika dibandingkan dengan nilai EAN maka diperoleh 4 ruas jalan Baubau-Kapuntori yang tergolong black site yang memiliki nilai EAN lebih besar dari nilai BKA yaitu Jalur M nilai EAN sebesar 730 dan BKA sebesar 174, Jalur J dengan nilai EAN sebedar 220 dan BKA 740, Jalur L nilai EAN sebesar 211 dan BKA sebesar 174, dan yang terakhir adalah JalurK dengan nilai EAN sebesar 205 dan BKA 40.

Secara grafis identifikasi black site dengan metode BKA dan UCL dapat dilihat pada Gambar 4.4 dan Gambar 4.5

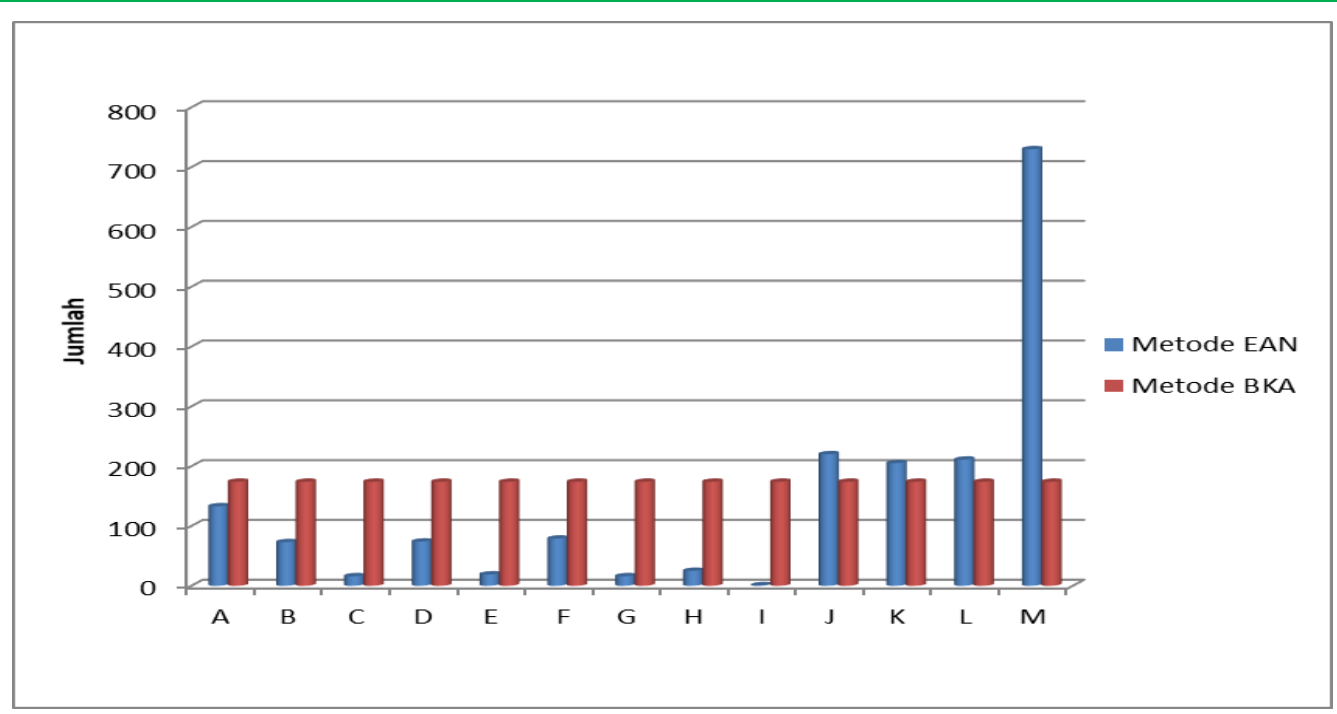

Gambar 4.4 Identifikasi Black Site dengan Metode BKA 


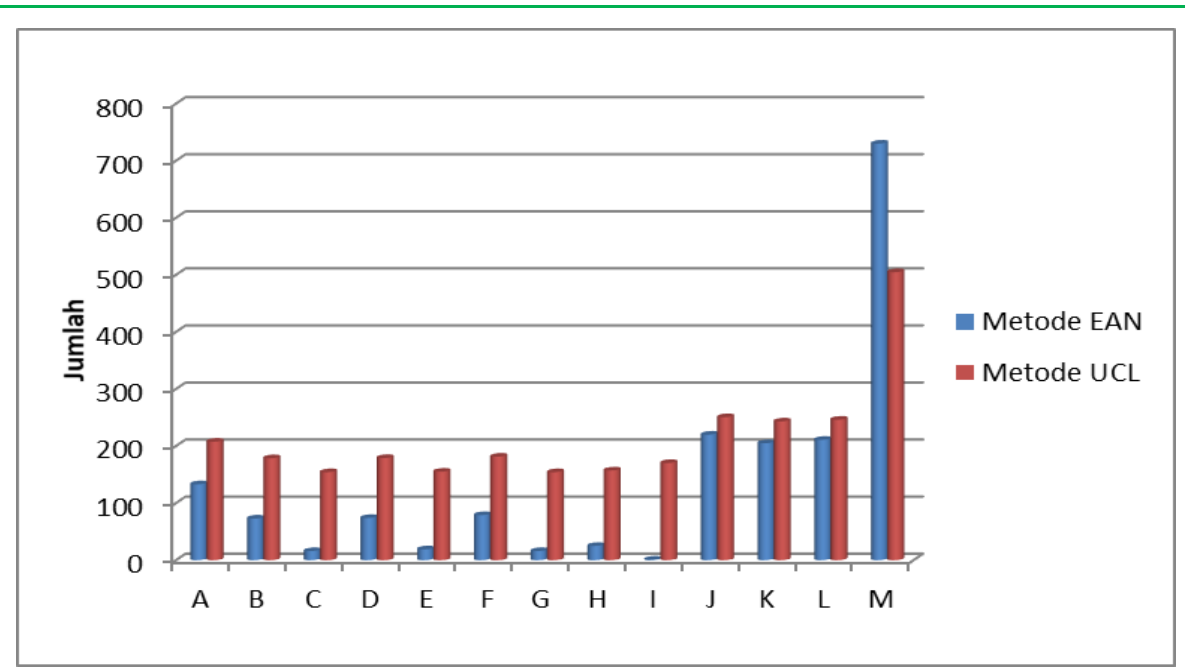

Gambar 4.5. Identifikasi Black Site dengan Metode UCL

Berdasarkan hasil perhitungan batas kontrol dengan metode BKA dan UCL seperti terlihat pada Gambar 6.6, teridentifikasi 1 ruas jalan pada Jalan BaubauKapuntori yang tergolong daerah rawan kecelakaan (blacksite) yaitu Jalur $M$, dengan nilai EAN sebesar 730 Lebih besar dari nilai batas kontrolnya $(B K A=174$ dan $U C L=504.7)$.

Daerah titik rawan kecelakaan (black spot) pada ruas jalan poros BaubauKapontori dengan menggunakan metode Z-Score, metode EAN, Metode BKA dan metode UCL diperlihatkan pada tabel 4.6 berikut ini.

Tabel 4.6 Daerah Black Spot berdasarkan metode Z-Score, EAN, BKA dan UCL

\begin{tabular}{cccccccc}
\hline Jalur & Z-Score & Ket. & $\begin{array}{c}\text { Metode } \\
\text { EAN }\end{array}$ & $\begin{array}{c}\text { Metode } \\
\text { BKA }\end{array}$ & Ket. & $\begin{array}{c}\text { Metode } \\
\text { UCL }\end{array}$ & Ket. \\
\hline A & 0,1 & $\begin{array}{c}\text { Black } \\
\text { Spot }\end{array}$ & 133 & 174 & - & 207,7 & - \\
\hline B & $-0,3$ & - & 73 & 174 & - & 178,7 & - \\
\hline C & $-0,7$ & - & 16 & 174 & - & 154,2 & - \\
\hline D & $-0,4$ & - & 74 & 174 & - & 179,1 & - \\
\hline E & $-0,6$ & - & 19 & 174 & - & 155,1 & - \\
\hline F & $-0,3$ & - & 79 & 174 & - & 181,5 & - \\
\hline G & $-0,7$ & - & 16 & 174 & - & 154,2 & - \\
\hline H & $-0,7$ & - & 25 & 174 & - & 157,2 & - \\
\hline I & $-0,8$ & - & 0 & 174 & - & 138,6 & - \\
\hline J & 0,2 & $\begin{array}{c}\text { Black } \\
\text { Spot }\end{array}$ & 220 & 174 & Black Spot & 250,6 & - \\
\hline K & 0,5 & $\begin{array}{c}\text { Black } \\
\text { Spot }\end{array}$ & 205 & 174 & Black Spot & 243,2 & - \\
\hline L & 0,5 & $\begin{array}{l}\text { Black } \\
\text { Spot }\end{array}$ & 211 & 174 & Black Spot & 246,2 & - \\
\hline M & 3,1 & $\begin{array}{l}\text { Black } \\
\text { Spot }\end{array}$ & 730 & 174 & Black Spot & 504,7 & Black Spot \\
\hline
\end{tabular}

\section{Kesimpulan}

Titik rawan kecelakaan (black spot) pada jalan poros Baubau-Kapontori adalah a) Titik rawan kecelakaan (black spot) menggunakan Metode Z-Score diperoleh 5 (lima) black spot yaitu Kadolomoko dengan nilai Z-Score 0,1, Desa Kamelanta dengan nilai Z-Score 0,2, Desa Lambusango dengan nilai Z-Score 0,5, 
Desa Lambusango Timur dengan nilai Z-Score 0,5 dan Kel. Wakangka 3,1. b) Titik rawan kecelakaan (black spot) menggunakan Metode EAN diperoleh 4 (empat) block spot yaitu Desa Kamelanta dengan nilai EAN 220, Desa Lambusango dengan nilai EAN 205, Desa Lambusango Timur dengan nilai EAN 211 dan Kel. Wakangka 730. C) Titik rawan kecelakaan (black spot) menggunakan Metode UCL diperoleh 1 (satu) blok spot yaitu Kel. Wakangka dengan nilai UCL 504,7

Ruas rawan kecelakaan (black link) pada jalan Poros Baubau-Kapontori berada pada daerah yang berawal dari Desa Kamelanta, Desa Lambusango, Desa Lambusango timur dan Kel. Wakangka.

\section{Daftar Pustaka}

Agustin, I. W., Meidiana, C., \& Muljaningsih, S. (2020). Studi Simulasi Model Kecelakaan Pengendara Mobil untuk Meningkatkan Keselamatan Lalu Lintas di Daerah Perkotaan. Warta Penelitian Perhubungan, 32(2). https://doi.org/10.25104/warlit.v32i2.1513

Enggarsasi, U., \& Sa'diyah, N. K. (2017). Kajian Terhadap Faktor-Faktor Penyebab Kecelakaan Lalu Lintas Dalam Upaya Perbaikan Pencegahan Kecelakaan Lalu Lintas. Perspektif, 22(3), 228. https://doi.org/10.30742/perspektif.v22i3.632

Ermawati, A. D., Sugiyanto, G., \& Indriyati, E. W. (2019). Penentuan Lokasi Rawan Kecelakaan Lalu Lintas dengan Pendekatan Fasilitas Perlengkapan Jalan di Kabupaten Purbalingga. Dinamika Rekayasa, 15(1), 65. https://doi.org/10.20884/1.dr.2019.15.1.258

Kusuma, Y., Sumarna, T., Mustika, D., \& Demar, M. (2019). Kinerja Rambu Lalu Lintas dan Dampaknya Pada Kecelakaan (Studi Kasus: Jalan Soekarno Hatta Bandung). Potensi: Jurnal Sipil Politeknik, 21(2), 61-64. https://doi.org/10.35313/potensi.v21i2.1597

Oktopianto, Y., \& Pangesty, S. (2021). Analisis Daerah Lokasi Rawan Kecelakaan Jalan Tol Tangerang-Merak. Jurnal Keselamatan Transportasi Jalan (Indonesian Journal of Road Safety), 8(1), 26-37. https://doi.org/10.46447/ktj.v8i1.301

Setiawan, D., \& Asima, M. (2019). Pemetaan Risiko Kecelakaan Lalu Lintas Di Ruas Jalan Tol Cipularang. Jurnal Teknik Sipil, 15(2), 100-113. https://doi.org/10.28932/jts.v15i2.1923

Setyarini, N. L. S. P. E., \& Lukito, B. I. (2020). Audit Keselamatan Jalan Tol Jagorawi. Jurnal Muara Sains, Teknologi, Kedokteran Dan Ilmu Kesehatan, 4(2), 403. https://doi.org/10.24912/jmstkik.v4i2.9056

Sugiyanto, G., \& Fadli, A. (2017). Identifikasi Lokasi Rawan Kecelakaan Lalu Lintas (Black Spot) di Kabupaten Purbalingga, Jawa Tengah. Jurnal Teknik Sipil Dan Perencanaan, 19(2), 128-135. https://doi.org/10.15294/jtsp.v19i2.10768 